\title{
The tools and methods of capturing knowledge from customers: empirical investigation
}

\author{
Nikita Plyasunov \\ GSOM Saint-Petersburg \\ State University, \\ Volhovsky per. 3 \\ Email: n1.0@mail.ru
}

\author{
Dmitry Kudryavtsev \\ GSOM Saint-Petersburg \\ State University, \\ Volhovsky per. 3 \\ Email: d.v.kudryavtsev@gsom.pu.ru
}

\author{
Liudmila Kokoulina \\ GSOM Saint-Petersburg \\ State University, \\ Volhovsky per. 3 \\ Email: ludmila.zubkova@gmail.com
}

\begin{abstract}
The goal of this research is to investigate the process of customer knowledge capturing, specifically knowledge coming from customers. We identified and classified tools and methods of capturing knowledge from customers. Both general tools from knowledge management and specialized ones from marketing research were considered. Besides, we aligned these tools and methods with the contextual factors using case studies from electrotechnical and software development industries, thus, the corresponding decision tree was suggested.
\end{abstract}

\section{INTRODUCTION}

$\mathrm{D}$ IFFERENT enterprise knowledge domains (e.g. product/service knowledge, customer knowledge, opera tions management or strategic management knowledge etc.) have different knowledge characteristics and knowledge types. As a result, different knowledge domains require specific methods and tools (Kudryavtsev, Menshikova, 2016; Kudryavtsev et al, 2017). A number of studies support the idea to differentiate KM methods and tools based on types and domains of knowledge. For example, Jobe and Schulz (Schulz, Jobe, 2001) have shown a positive relationship between the "focused" KM strategy and performance of the company on the basis of empirical research. "Focused" strategy involves the use of different methods of knowledge codification based on the type of knowledge.

Customer knowledge plays an important role in every organization. Researchers and practitioners have focused on customer orientation as a source of competitive advantage for a long time. According to Kohli and Jaworski (1990), customer orientation suggests different activities that are related to information generation, dissemination, and corresponding responses to customer needs and preferences, both current and future ones. For instance, customer orientation is aligned to a degree organization captures and uses information from customers, converts this information into a strategy for meeting customer needs, and implements that strat- egy by appropriately responding to and meeting customer needs (Hooley and Theoharakis, 2008).

In addition, Narver and Slater (1990) described customer orientation as an important element of market orientation which is linked to organizational performance by multiple studies. Moreover, Saad et al. (2015) state that customer orientation of the firm is a key part of the marketing concept itself. Therefore, the role of customer orientation cannot be overestimated for a modern company.

Consequently, in order to respond to customer needs and requirements and to eventually satisfy them, possessing of relevant customer knowledge is important for an organization. We have chosen to focus on one type of customer knowledge, namely knowledge received FROM customers. So the aim of the paper is to identify tools and methods of capturing knowledge from customers and to understand contextual factors, which influence the choice of a particular tool/method.

The paper is structured as follows. First, we provide a short literature overview with a theoretical background of the research. Then we introduce the methodology of the study. In the following section, we describe the results of the study and discuss implications of the study results.

\section{Theoretical Backround}

The present research is built upon marketing (specifically, customer knowledge concept) and knowledge management (knowledge capturing) theories.

Knowledge, as well as customer knowledge, can be tacit or implicit. Therefore, different methods of knowledge capturing should be used for various types of customer knowledge (Nonaka and Takeuchi, 1995). In the next subsections, short literature review of customer knowledge concept and customer knowledge classification, as well as the review of knowledge capturing tools are provided. 


\section{A. Customer Knowledge}

Researchers state that the customer knowledge is either the knowledge that an organization has about its customers or knowledge about an organization, its products or services, that customers possess (Campbell, 2003; Mitussis et al.,2006; Lee et al., 2011). Customer knowledge is a comprehensive term and the definition itself depends on a source of knowledge (Nejatian et al., 2011).

Customer knowledge reflects the way the company understands its current and future customers' needs and preferences (Lee et al., 2011). Feng and Tian (2005), based on Gebert et al. (2002) define customer knowledge as "the dynamic combination of experience, value and insight information needed, created and absorbed during the process of transaction and exchange between the customers and enterprise". Campbell (2003) defines customer knowledge as the "organized and structured information about the customer as a result of systematic processing". According to Mitussis et al. (2006), customer knowledge can be defined as a comprehensive type of knowledge, because customer knowledge may be acquired from different sources and channels (Nejatian et al., 2011). Companies usually capture customer knowledge by interactions and dialogues with customers, by observing the ways customers use products or experience service, as well as by analyzing corporate data and information in order to forecast customer behaviour (Wayland and Cole, 1997).

In his research of 108 Fortune 500 companies, Harlow (2008) stated that companies with developed knowledge management approaches and tools have higher effectiveness of innovation activities. It means that use of knowledge management tools allows company to be more successful in terms of new product development.

As for marketing perspective, capturing information or knowledge from customers is traditionally viewed as a part of the market research or, in particular, the customer research. Organizations use different tools and methods to provide this. General methods and tools of capturing knowledge from customers are mainly mentioned in knowledge management literature and toolboxes, such as Asian Productivity Organization knowledge management tools and techniques manual (2010), UNICEF knowledge exchange toolbox (2015), (Gavrilova, Andreeva, 2012) ; and specialized tools of knowledge capturing from customers mainly used within marketing for market and customer research. Some of the specialized tools are used online.

\section{B. Customer Knowledge Classifications}

There are several classification criteria for customer knowledge. First, customer knowledge can be classified as follows: knowledge about customers; knowledge from customers; knowledge for customers (Gebert et al., 2002; Feng and Tian, 2005). Knowledge from customers has a particular significance for modern organizations, as customers can contribute to the organizations` understanding of current and future products or services, strengths and weaknesses, etc. (Wayland and Cole, 1997; Zack, 2003; Paquette, 2006). Relations with organizations enable customers to have their opinions, thoughts, ideas, satisfied or non-satisfied needs, and they may share this knowledge with the organization. This knowledge can be used within the organization for different purposes, the main such purposes are products or services' quality improvement, new product development (NPD), market or customer research and other purposes that depend on individual organization (Paquette, 2006; Laage-Hellman et al., 2014).

Second classification of customer knowledge is the split into tacit and explicit knowledge. Helie and Sun (2010) characterized explicit knowledge as "knowledge that can be readily articulated, codified, accessed and verbalized". To put it differently, it is the description of theories, methods, techniques, technologies, machines and mechanisms, structures, systems, etc. Explicit knowledge is stored in the actual physical media (books, paper documents, drawings, diagrams, movies, databases, etc). It means that this type of knowledge is a storage and it is easier to process and use this knowledge.

As for tacit knowledge, it is personal knowledge, inseparable from individual experience. It can be transmitted by direct contact - "face to face" or using special procedures of knowledge extraction.

Customers accumulate the knowledge about products or services they have and use, and they actually may contribute it into company`s learning process (Zack, 2003). According to Paquette (2006), customers can provide the organization with unique knowledge that may be used for improving its internal operations, including innovation and new product development. On the other hand, the organization provides a customer with knowledge of its products and services, which makes customer more informed about the company, and, therefore, the customer may become loyal to the company. This two-way flow of knowledge allows company to create a competitive advantage based on relationship, or probably, partnership with the customer.

To summarize definitions and statements mentioned above, customer knowledge may be both:

- Structured information, facts, knowledge that company has about its customers, and their needs, preferences

- Knowledge that a customer possesses in the form of experience, value and insight information. In this case, knowledge is not codified; it is "stored" in minds of customers, so it can be identified as tacit knowledge. It means that it is difficult to acquire this type of knowledge, because it deals with state of mind of customers, however, it is important to consider this type of knowledge due to potential source of insights and ideas (Crié and Micheaux (2006).

Another approach to customer knowledge classification was proposed by Crié and Micheaux (2006). The authors divide customer knowledge into two types, namely: "Behavioral", that may be easily captured and is basically quantitative in its nature (transactional data), and "Attitudinal" that can hardly be captured, but it suggests customer ideas and insights.

However, this research used the following classification (Tseng, Wu, 2014; Gebert, 2002): 
- Knowledge FOR customers: knowledge, provided to customers to satisfy their needs;

- Knowledge ABOUT customers: knowledge about customers to optimize customer profiling and segmentation, and campaign management processes.

- Knowledge FROM customers: knowledge possessed by customers and obtained by organizations by interacting with them.

This paper is focused on the third type of customer knowledge, knowledge from customers. As far as the authors know, there are no academic studies related specifically to this type of knowledge. The next subsection covers this type of customer knowledge in detail.

\section{Knowledge FROM Customers}

Wang and $\mathrm{Yu}$ (2010) state that knowledge from customers refers to the feedback to the company, its products and services, competitiveness, that can be acquired from a customer. Development of technologies provides for increased amount of information that is available to customers, and today, consumers can easily develop their own opinions regarding the company, its products or services (Tseng and $\mathrm{Wu}, 2014)$. What is more, customers are paying more attention to the quality of products and services they are consuming, rather than the price (still, the price is also important), and this statement is especially truthful for non-consumable goods (Garcia-Murillo and Annabi, 2002).

According to Fang and Tsai (2005), the companies should consider customer expectations, because it would provide for satisfying service and development of the service quality. Mithas et al. (2005) also stated that through communication and interaction with customers, the company can gain customer knowledge related to new demands about products or services that can be helpful references for improvement; moreover, this process is beneficial for customer satisfaction, customer loyalty and employee productivity. Therefore, the purposes of capturing knowledge from customers are quite various, ranging from new product development and quality of products/services enhancements to conducting comprehensive market researches in order to understand trends, customer needs and wishes, or other things depending on the company and its goals.

In addition, such forms or representations as opinions, feedback, insights, requirements, and ideas may be considered as knowledge from customers.

The object of knowledge from customers (what exactly customers may know about organization) may also vary (Gebert et al., 2002; Paquette, 2006; Laage-Hellman et al., 2014): knowledge about products, knowledge about services, knowledge about brand, knowledge about business processes, knowledge about market, knowledge about partners.

We summarized the review of knowledge from customers in fig. 1 .

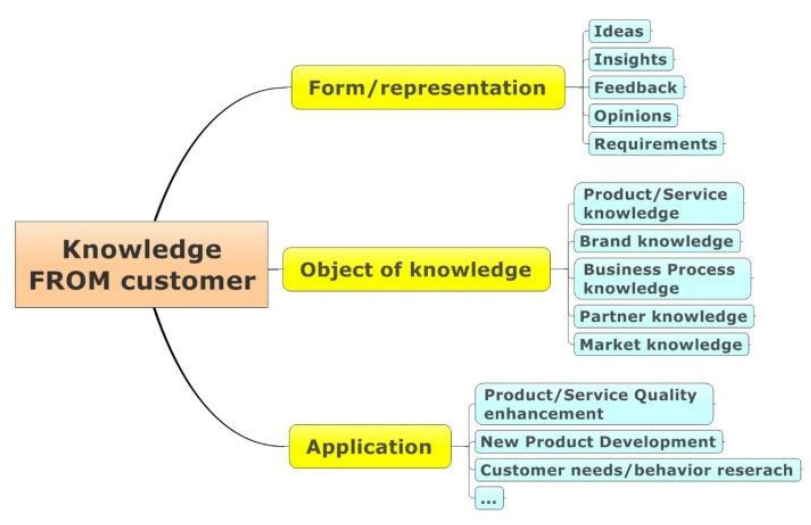

Fig. 1 Overview of knowledge FROM customer

\section{RESEARCH METHODOLOGY}

As the aim of the paper was to identify tools and methods of capturing knowledge from customers and to understand contextual factors, which influence the choice of a particular tool/method, research is mostly of exploratory nature, we have chosen a qualitative approach. Literature review, case study, semi-structured interviews and document analysis were employed for our research.

The study was conducted in three phases.

First, literature review was undertaken. Based on the results of the literature analysis, a preliminary classification of tools for capturing knowledge from customers was developed. Since factors, which influence the selection of tools, were also in the focus of the research, a framework for analysis of the context of choosing and using the tools of capturing knowledge from customers was found. The choice fell on 4W framework (Sergeeva and Andreeva, 2014) based on Johns' (2006) "Who? Where? Why? What?" framework. The framework helped to formulate four main questions, answering which allows disclosing the context:

- WHO are the customers of the company?

- WHAT types and forms of knowledge from customers are collected?

- What are the targets of the company, why it captures knowledge from the customer? (WHY?)

- What is the company itself, the culture, management style, level of maturity, industry, etc. (WHERE?)

During the second phase preliminary in-depth interviews with 3 knowledge management and strategic consultants were conducted. Preliminary classification of tools for capturing knowledge from customers was demonstrated to them and feedback was collected. These interviews helped to improve classification of tools (see Appendix, Figure A.1) and fine-tune questions for the third phase.

The third phase involved the multiple case study method. 6 companies (cases) from two marketing-driven and knowledge-intensive industries were analysed: 3 electrotechnical multinational corporations (companies A, B, C) and 3 software development firms (companies D, E, F). All these companies are operating at Russain market. The primary source of data was in-depth interviews, the secondary source - the companies` web sites, corporate reports and industry analytics. We conducted 6 semi- 
structured interviews, which lasted for 60-90 minutes each with experts from these companies. The questions discussed were related to the process of customer knowledge capturing and to the suggested classification of tools. The classification was printed out and given to respondents.

All interviews were tape recorded, transcribed and translated from Russian to English for analysis.

\section{RESULTS AND DISCUSSION}

Based on the results of the literature analysis and in-depth interviews with 3 knowledge management and strategic consultants, a preliminary classification of tools for capturing knowledge from customers was developed (see Appendix, Figure A.1).

Multiple case study helped to identify contextual factors, which influence application of tools for capturing knowledge from customers within electrotechnical and software development industries.

\section{A. Electro-Technical Industry}

In terms of corporate strategy, all respondents stated that localization of products is a key point for the Russian market (since only multinational corporations were analyzed in this industry). That is why market and customer knowledge is important for them.

We did not found any evidence that management style and organizational culture interrelate with the choice of customer knowledge capturing tools. However, the company that claims to be customer driven and has close relations with customers uses simple and customer-friendly tools and methods such as surveys, feedback forms, etc.

According to all respondents, forms or representations of knowledge may be different: insights, feedback, ideas, and requirements. Almost every form of information from customers that may be used by the company is defined as customer knowledge. However, types of knowledge are different. All companies stated that they used different types of knowledge from customers: product knowledge, market knowledge, business process knowledge.

In this case, product knowledge accumulates all types of information and knowledge about the company`s products that customers possess. For example, features of desired products, positive or negative experience linked to a product is referred to as product knowledge. All contacted companies use product knowledge for different purposes.

Here, market knowledge is knowledge of market trends, competitor analysis, customer preferences and trends, etc. There are different reasons for capturing market knowledge from customers: one company uses surveys and questionnaires among its major customers in order to collect market knowledge for opportunity identification, new product development, market penetration. Company B uses market knowledge for market research purposes and orders market research from third parties. Company $\mathrm{C}$, as well as company A, uses surveys and questionnaires for strategic purposes.

Business process knowledge, or knowledge of customer technologies, is used by all companies for different purposes. Company A and $\mathrm{C}$ serve large customers with sophisticated projects where NPD is impossible without considering concrete requirements from customer in terms of business processes and technologies. Company B also uses business process knowledge as well as product knowledge for NPD to satisfy needs of customers (especially from construction industry).

To sum up, types of knowledge and forms of knowledge are quite strong determinants of tools' and methods' selection. However, the type of knowledge alone does not influence the choice of tools and methods; the specific goal of knowledge usage is significant. For example, surveys can be used in both product knowledge for measuring customer satisfaction and market knowledge for identifying market trends.

Reasons and purposes why company captures knowledge from customers is an important determinant for a choice of knowledge capturing instrument. All respondents agreed that before using particular tools or method of capturing customer knowledge, first thing to consider is the purpose of using knowledge from customer. New product development and quality enhancements involve quite different tools. According to respondents, knowledge from customers is used to achieve the following goals:

- Market research;

- New product development;

- Quality enhancements;

- Product localization;

- Customer satisfaction assessment;

- Product requirements and standard clarification;

- Internal business process improvement.

Market research provides for usage of different tools. Company A and company B use different approaches to market research. While company A conducts surveys and sends questionnaires to its customers, company B prefers to use third-party market researches. Like Company A, Company $\mathrm{C}$ also uses surveys for its customers.

New product development for sophisticated projects is organized in companies $\mathrm{A}$ and $\mathrm{C}$ as follows: brainstorming sessions with customer representatives are used for feature discussions, idea generation of needed functions. Company B also uses brainstorming sessions for same purposes.

Product quality enhancements are mostly managed by trial operations or "test drives", where product is tested by customer with succeeding customer's feedback with regard to possible changes or improvements using this tool. Other tools of quality enhancements applied by all companies include feedback forms on web sites, call centers, sometimes, focus groups.

Product localization is closely linked to NPD and quality enhancements, so the tools used for this purpose are the same.

Customer satisfaction assessment is an important sphere or goal of customer knowledge application, as it provides for the opportunity to the company to understand its products' suitability for customers. As for tools and methods, all contacted companies use surveys (NPS score), mailout asking for feedback, feedback forms on web sites, call centers. Company $\mathrm{A}$ and $\mathrm{C}$ use sentiment analysis in order to identify whether final customers are satisfied or not (mostly for consumer goods, where final customers are people able to leave comments, reviews, feedback on the web, so it is not applicable for business customers). Company B uses 
social networks, blogs and forums for this purpose, where it analyzes feedback from final customers as well.

Product requirements' and standards' clarifications are applied by all companies, because they follow their localization strategy, and all new and existing products should be localized for the Russian market. For this purpose, companies contact engineering centers' (design institutions) representatives and conduct interviews or organize workshops, in order to clarify these requirements and standards for products.

Internal business improvement was mentioned just once, in an interview with the company B. They stated that usage of call centers, and web site feedback forms sometimes leads to improvement of internal business processes because customers notice some controversial things need to be improved.

As different industries suggest different type of customers, this dimension may influence the choice of instruments. In author`s cases, all contacted companies have two major types of customers: direct and non-direct. Direct ones can be defined as customers that buy products or services from contacted companies. Non-direct customers are defined as influential customers; their knowledge influence companies`decisions.

First, direct customers. Company A, and company C together have b2b customers in the form of distributors, retailers. While company $\mathrm{B}$ works directly with its customers who are large maintenance and construction companies, without third parties. In latter case, closer customer relations that include special technical consultant that realizes complex customer care before and after sales, relieves the company from usage of significant number of instruments of capturing knowledge from customers. Company $\mathrm{A}$ and company $\mathrm{C}$ also work directly with large companies in implementing complex energy networks, processes automation projects, etc. In this case, customer relations are close enough, however they are organized in a bit another way: meetings with customer representatives is major type of communication and knowledge capturing process.

Second, non-direct customers. All contacted companies from electrotechnical industry stated that in order to localize its products for Russian market they also contact so-called engineering centers of design institutions in order to clarify official requirements and standards for products. It is an important step in launching new products to Russian market.

What is more, company A and company $\mathrm{C}$ noted that designers, architects and integrators are important non-direct customers too. That is because these 2 companies produce products that are used in design and repair activities in apartments, such as power sockets, counters, switchers, etc. The reason of this fact is quite simple. Interior designers and architects may advise final customers to install products by well-known companies, because they are better quality and design. Therefore, companies are interested in this type of non-direct customers due to insights supply and knowledge that can be used for NPD, product design, etc.

To sum it up, customers as determiners of context of choosing and using instruments and methods of capturing knowledge from customers in electrotechnical industry play moderate role. Type of customer may influence the choice of instruments and methods, but it depends primarily on how company organizes its customer communication processes.

TABLE 1.

CONTEXT IN ELECTRO-TECHNICAL INDUSTRY.

\begin{tabular}{|c|c|}
\hline Strategy & Localization of products for Russian market \\
\hline Customers & $\begin{array}{c}\text { Direct customers (distributors and retailers; } \\
\text { industry companies), non-direct customers } \\
\text { (final buyers; engineering centers; designers, } \\
\text { architects, integrators) }\end{array}$ \\
\hline $\begin{array}{c}\text { Forms of } \\
\text { knowledge }\end{array}$ & $\begin{array}{c}\text { Insights, requirements, feedback, ideas, } \\
\text { thoughts }\end{array}$ \\
\hline
\end{tabular}

TABLE 2.

KNOWLEDGE CAPTURING IN ELECTRO-TECHNICAL INDUSTRY.

\begin{tabular}{|c|c|c|}
\hline $\begin{array}{l}\text { Types of } \\
\text { knowledge }\end{array}$ & $\begin{array}{l}\text { Applications/ } \\
\text { goals }\end{array}$ & $\begin{array}{l}\text { Instruments of capturing } \\
\text { knowledge from } \\
\text { customers }\end{array}$ \\
\hline $\begin{array}{c}\text { Market } \\
\text { knowledge }\end{array}$ & $\begin{array}{l}\text { Market } \\
\text { research }\end{array}$ & $\begin{array}{c}\text { Surveys, Questionnaires, } \\
\text { Partner portal }\end{array}$ \\
\hline \multirow[t]{2}{*}{$\begin{array}{c}\text { Product } \\
\text { knowledge }\end{array}$} & $\begin{array}{c}\text { Quality } \\
\text { enhancements }\end{array}$ & Focus groups \\
\hline & $\begin{array}{c}\text { Customer } \\
\text { satisfaction } \\
\text { assessment }\end{array}$ & NPS surveys \\
\hline \multirow{2}{*}{$\begin{array}{c}\text { Product } \\
\text { knowledge, } \\
\text { Business } \\
\text { process } \\
\text { knowledge }\end{array}$} & NPD & $\begin{array}{l}\text { Brainstorming, content } \\
\text { analysis, surveys, focus } \\
\text { groups, interviews }\end{array}$ \\
\hline & $\begin{array}{c}\text { Quality } \\
\text { enhancements }\end{array}$ & $\begin{array}{l}\text { Test drives (trial operation } \\
\text { period); surveys }\end{array}$ \\
\hline $\begin{array}{c}\text { Product } \\
\text { knowledge }\end{array}$ & $\begin{array}{c}\text { Customer } \\
\text { satisfaction } \\
\text { measurement } \\
\end{array}$ & $\begin{array}{l}\text { Feedback forms on web } \\
\text { site; Surveys; call-centers; } \\
\text { sentiment analysis }\end{array}$ \\
\hline $\begin{array}{c}\text { Product } \\
\text { knowledge } \\
\text { (requirements } \\
\text { and standards) } \\
\end{array}$ & $\begin{array}{c}\text { Product } \\
\text { localization }\end{array}$ & Interviews \\
\hline $\begin{array}{c}\text { Product } \\
\text { knowledge }\end{array}$ & $\begin{array}{l}\text { NPD (design, } \\
\text { features, } \\
\text { standards) }\end{array}$ & Interviews; Blogs \\
\hline
\end{tabular}

\section{B. Software Development Industry}

There is a significant number of differences with electro technical industry in both tools and methods of capturing knowledge from customers, and basis of these tools and methods' choosing and application.

Development approach defines the whole software development cycle. Two well-known approaches to development used by respondent companies are Waterfall approach and Agile approach.

Waterfall approach, or waterfall model, involves consistent implementation of all phases of the project in a fixed sequence. The transition to the next stage means full completion of the previous phase. The requirements specified during the stage of requirements elicitation are strictly documented as technical specifications and fixed for the period of project development. At the end of each stage, a complete set of documentation is released, and this set shall be sufficient to ensure that the development may be 
continued by another development team. Therefore, this approach suggests a lot of documentation and procedures linked to requirements gathering from customers.

Agile approach involves the use of iterative development, a dynamic requirements elicitation, and provision of their implementation by means of constant interaction within the self-organizing working groups, consisting of experts in various fields, and close relations with customers (Agile Alliance, 2015). Therefore, Agile approach means more flexibility, less bureaucracy and documentation, and less application of tools. According to company $\mathrm{E}$ and company $\mathrm{F}$ representatives, main tools are communication and company specialists' minds.

What is more, company strategy is also significant. For example, company D operates mostly on the Russian market, and it is a large player on this market, while company $\mathrm{E}$ and company $\mathrm{F}$ are international companies, and their customers are mostly large non-Russian companies. Therefore, their strategy on the Russian market includes finding excellent qualified employees and being attractive employer for them. According to company $\mathrm{E}$ and company $\mathrm{F}$ representatives, working with large international companies provides that requirements mainly have already been formalized on customer's side, and there is no need to use special tools and methods of capturing knowledge from customers for this purpose.

Meanwhile, working with the majority of Russian customers involves company-based, not customer-based, collecting and formalization of requirements to a product. Therefore, the customers' characteristics are also important in the software development industry. It is not necessarily a rule that Russian companies do not have formalized requirements, when working with software development companies.

As for customers in general, all three contacted companies (D, E, F) stated that they worked with large, enterprise-class companies and state organizations operating in different industries. However, company F focuses mostly on financial, telecommunication, and R\&D companies, while companies D and E have no clear industry focus.

All respondents from software development claimed that they needed to know the finest details about customers businesses. Therefore, business process knowledge and technology knowledge are main focus of knowledge from customers. Sometimes (company D), companies also capture market knowledge that includes knowledge about their former and existing clients and their needs. Alternatively, it appears as potential customer insights and opinions with regard to new service prototypes.

The use and application goals for tools and methods of capturing knowledge from customers in software development industry are quite predictable. Companies collect knowledge from customer to learn which service or product they should develop. All of three contacted companies use service/product requirements for new service/product development. Moreover, the process of development includes trial operation periods where customers test software and give feedback to the company, make changes. Thus, quality enhancements as tools and methods' application are also applied in software development companies.
TABLE 3.

CONTEXT IN SOFTWARE DEVELOPMENT INDUSTRY.

\begin{tabular}{|c|c|}
\hline Strategy & $\begin{array}{c}\text { Duplication of company`s services to broad } \\
\text { market - Non-agile (e.g. waterfall); } \\
\text { Being attractive employer, talent acquisition - } \\
\text { Agile (e.g., Scrum) }\end{array}$ \\
\hline Customers & Large companies; state organizations \\
\hline $\begin{array}{c}\text { Forms of } \\
\text { knowledge }\end{array}$ & Requirements; feedback; opinions; thougts \\
\hline
\end{tabular}

TABLE 4.

KNOWLEDGE CAPTURING IN SOFTWARE DEVELOPMENT INDUSTRY.

\begin{tabular}{|c|c|c|}
\hline $\begin{array}{c}\text { Types of } \\
\text { knowledge }\end{array}$ & $\begin{array}{l}\text { Applications/ } \\
\text { goals }\end{array}$ & $\begin{array}{l}\text { Instruments of } \\
\text { capturing knowledge } \\
\text { from customers }\end{array}$ \\
\hline \multirow{4}{*}{$\begin{array}{c}\text { Product } \\
\text { requirements } \\
\text { (and product } \\
\text { knowledge); } \\
\text { Business } \\
\text { process } \\
\text { knowledge }\end{array}$} & NPD & $\begin{array}{c}\text { Wiki; Brainstorming } \\
\text { sessions; Content } \\
\text { analysis; Focus groups; } \\
\text { Interviews } \\
\end{array}$ \\
\hline & $\begin{array}{c}\text { Quality } \\
\text { enhancements }\end{array}$ & $\begin{array}{c}\text { Test drives (trial } \\
\text { operation period); Task } \\
\text { trackers; Wiki; } \\
\text { Brainstorming sessions }\end{array}$ \\
\hline & $\begin{array}{c}\text { Customer } \\
\text { satisfaction } \\
\text { assessment }\end{array}$ & $\begin{array}{l}\text { Surveys; Questionnaires; } \\
\text { Interviews }\end{array}$ \\
\hline & $\begin{array}{l}\text { Beginning of } \\
\text { relations with } \\
\text { customer } \\
\end{array}$ & $\begin{array}{l}\text { Questionnaires; } \\
\text { Interviews }\end{array}$ \\
\hline \multirow[t]{2}{*}{$\begin{array}{r}\text { Market } \\
\text { knowledge }\end{array}$} & $\begin{array}{l}\text { Market research } \\
\text { (probable needs of } \\
\text { current and former } \\
\text { customers) }\end{array}$ & Questionnaires \\
\hline & $\begin{array}{l}\text { Market research } \\
\text { (collection of } \\
\text { opinions and } \\
\text { insights of alpha } \\
\text { product) }\end{array}$ & $\begin{array}{l}\text { Seminars/webinars; } \\
\text { design thinking tools }\end{array}$ \\
\hline
\end{tabular}

Customer satisfaction analysis or assessment is important, however, not each company uses tools and methods of capturing knowledge from customers for this purpose. Company D, following the non-Agile approach of software development, uses formal questionnaires to accomplish this task, while companies $\mathrm{E}$ and $\mathrm{F}$, following Agile approach, learn about customer satisfaction or dissatisfaction by simple continuous communication process.

Sometimes companies use knowledge from customers to collect insights from potential customers, in order to use them in NPD, or conduct market research, in order to identify needs of their former and existing customers by offering them a different product or service (company D).

Thus, we found out that the approach to software development is an important determinant of knowledge capturing choice. Agile-based methodologies or approaches to software development clearly define usage of tools and methods of capturing knowledge from customers. Findings showed that companies which follow Agile do not simply focus on lots of these tools and methods, for Agile-based approaches do not respect comprehensive documentation, sophisticated processes, and a broad range of tools. 
Communication is everything for them. On the other hand, implementation of non-Agile approaches in companies involves these tools and methods.

\section{CONCLUSION}

Knowledge from customers plays an important role in customer-oriented business and can be applied for the NPD, improvement of products or services, for market or customer research purposes and other goals.

The classification of tools and methods of capturing knowledge from customers was established during the research. The split into general tools of knowledge management and specialized tools of capturing knowledge from customers was made.

The following determinants of the knowledge capturing tool were identified:

- The strategy of the company; approach to software development (for software development industry), organizational culture and management style (for electrotechnical companies). This was used to define, if applicable, internal motives of application or non-application of knowledge from customers and, therefore, tools of this knowledge capture;

- The definition of case companies' customers intended for their classification;

- Forms of knowledge and objects of knowledge to show the exact knowledge from customers received by the case company;

- Applications or goals of using knowledge from customers, to put it differently, why company applies knowledge from customers and capture tools;
The main findings could be summarized as follows:

- For the electro-technical industry, the first step in choosing the tool or method of capturing knowledge from customers is identification of the application goal, while for the software development, the primary thing influencing the choice is the approach or methodology of the software development.

- For the electro-technical industry, determination of the goal of using knowledge from customers is followed by company's decision on which customers should be involved in the knowledge from customer process.

- For the software development industry, when the development approach or methodology is known, the goal or application of knowledge from customers and, therefore, tools of capturing this knowledge should be defined.

The comparison between two industries is revealed and presented as a decision tree (see Appendix, Figure A.2). Decision tree shows the way the most influential dimensions of the context influence the choice of tools among electrotechnical and software development industries.

The present paper contributes to the customer orientation theories by providing for the knowledge management perspective. Besides, the study is providing for the context to the knowledge capturing tools analysis. Therefore, the study results are valuable for practitioners interested in customer knowledge capturing techniques. Moreover, the study sheds the light on the underexplored subject of knowledge from customers by providing illustrations of such knowledge for two knowledge intensive and marketing driven industries.

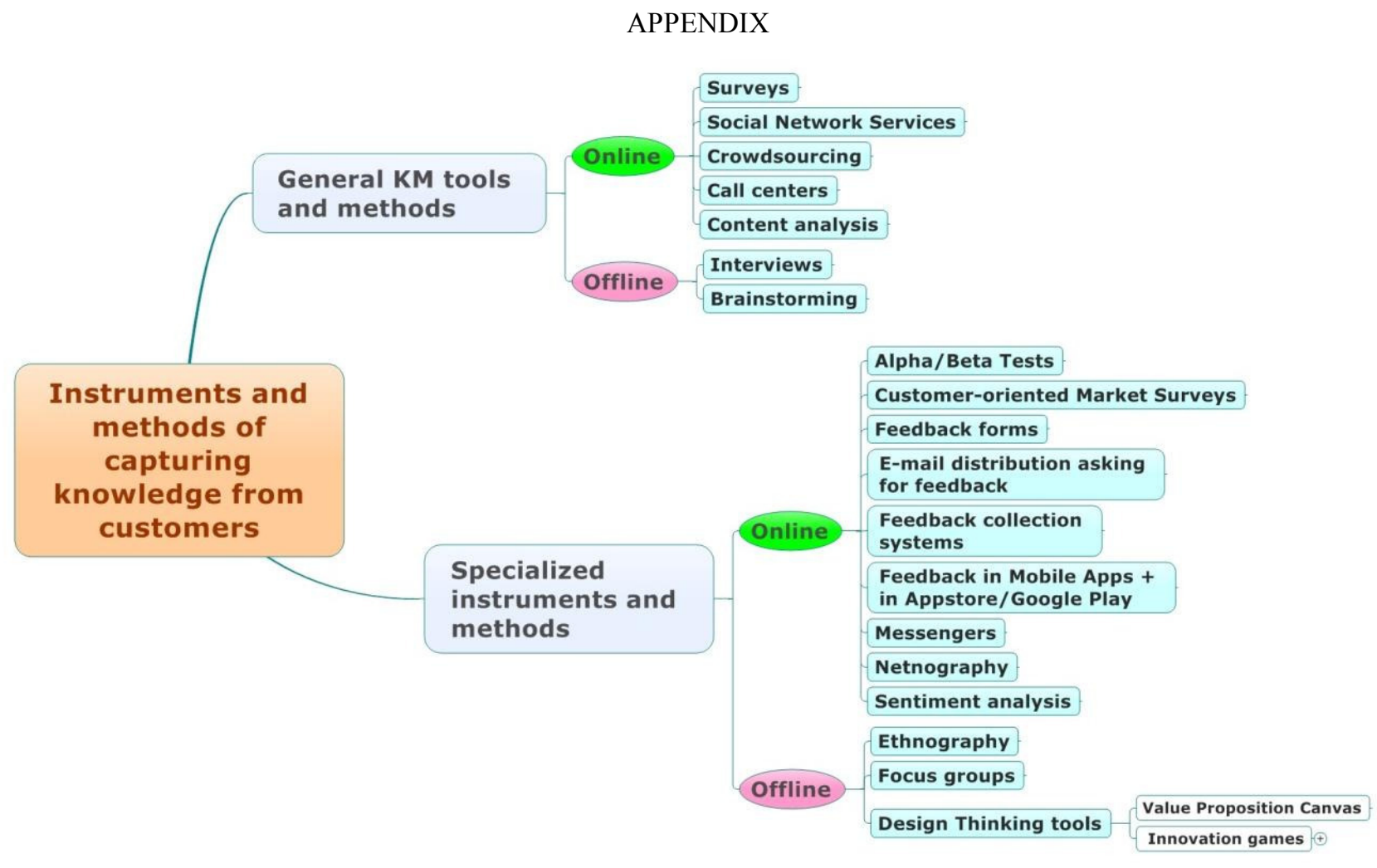

Fig. A.1. Tools and methods of capturing knowledge from customers 


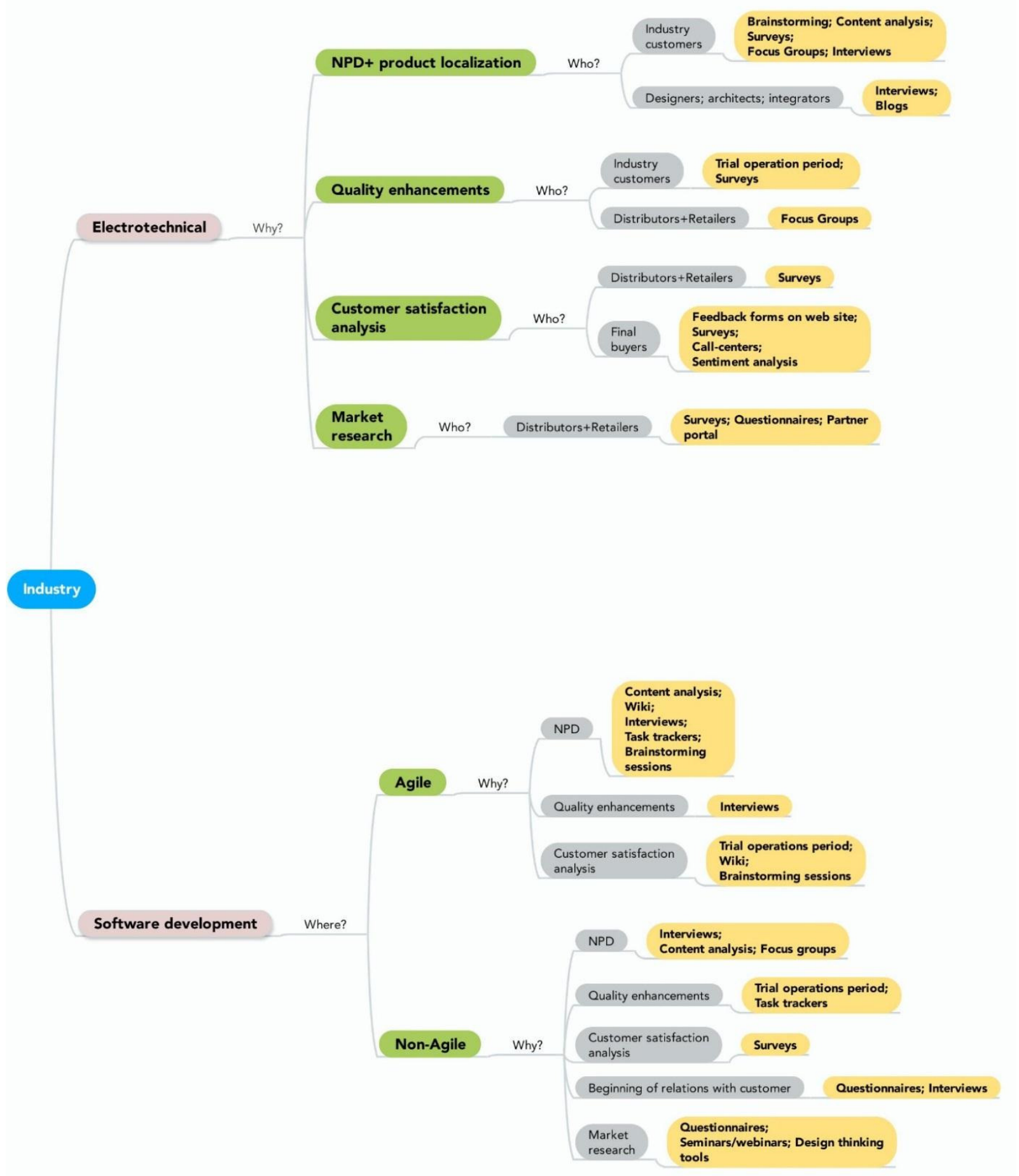

Fig. A.2. Decision tree of tools and methods of capturing knowledge from customers

\section{ACKNOWLEDGMENT}

Research has been conducted with financial support from Russian Science Foundation grant (project No. 15-1830048).

\section{REFERENCES}

A.J. Campbell, "Creating customer knowledge competence: managing customer relationship management programs strategically". Industrial Marketing Management, Vol. 32 No. 5, 2003. pp. 375-83. 
[2] S. C. Fang, F.S. Tsai, "Knowledge sharing routines, task efficiency, and team service quality in instant service-giving settings". The Journal of American Academy of Business. Vol. 6 No. 1, 2005. pp. 62-67.

[3] T. Gavrilova, T. Andreeva, "Knowledge elicitation techniques in a knowledge management context", Journal of Knowledge Management, Vol. 16, Iss: 4, 2012, pp. $523-537$

[4] T. X. Feng, J. X. Tian, "CKM and condition analysis of successful CKM implementation". In the Fourth International Conference on Machine Learning and Cybernetics, 18 - 21 August 2005, Guangzhou, 2005. pp. 2239-2244

[5] M. García-Murillo, H. Annabi, "Customer knowledge management". Journal of Operations Research Society, 53(8), 2002. pp. 875-884.

[6] H. Gebert, M.Geib, L. Kolbe, W. Brenner, "Knowledge-enabled customer relationship management: integrating customer relationship management and knowledge management concepts". Journal of Knowledge Management. Vol. 7 Iss: 5, 2002. pp.107 - 123.

[7] H. Harlow, "The effect of tacit knowledge on firm performance". Journal of Knowledge Management. 12(1), 2008. pp. 148-163.

[8] Helie,S; Sun, R., "Incubation, Insight, and Creative Problem Solving: A Unified Theory and a Connectionist Model". Psychology Review 117 (3): 2010. pp. 994-1024.

[9] G. J. Hooley, V. Theoharakis, "Customer orientation and innovativeness: Differing roles in new and old Europe". International Journal of Research in Marketing, 25(1), 2008. pp. 69-79.

[10] G. Johns, "The essential impact of context on organizational behaviour". Academy of management review, 31(2), 2006. pp. 386-408.

[11] A. Kohli, B. Jaworski, Market Orientation: The Construct, Research Propositions, and Managerial Implications. Journal Of Marketing, 54(2), 1990. pp. 1-18.

[12] D. Kudryavtsev, A. Menshikova, "Knowledge Domains, Types and Tools: An Interrelation Attempt", Proceedings of 11th International Forum on Knowledge Asset Dynamics IFKAD, Dresden, 2016, pp. 2200-2211.

[13] D. Kudryavtsev, A. Menshikova, T. Gavrilova, "Knowledge Management Tools: Universal and Domain-Specific". Proceedings of 12th International Forum on Knowledge Asset Dynamics IFKAD, Saint-Petersburg, 2017.

[14] J., Laage-Hellman, F. Lind, A. Perna, "Customer Involvement in Product Development: An Industrial Network Perspective", Journal Of Business-To-Business Marketing, 21(4), 2014. pp. 257-276.
[15] R. Lee, G.Naylor, Q. Chen, "Linking customer resources to firm success: The role of marketing program implementation". Journal Of Business Research, 64(4), 2011. pp. 394-400.

[16] S. Mithas, M. S. Krishnan, C. Fornell, "Why Do Customer Relationship Management Applications Affect Customer Satisfaction?". Journal of Marketing. (69:4), 2005. pp. 201-209.

[17] J.C. Naver, S.F. Slater, "The effect of a market orientation on business profitability". Journal of Marketing, 54, 1990. pp. 20-35.

[18] H. Nejatian, I.Sentosa, S. Piaralal, A. Bohari, "The Influence of Customer Knowledge on CRM Performance of Malaysian ICT Companies: A Structural Equation Modeling Approach”. IJBM, 6(7). 2011. pp. 181-198.

[19] I. Nonaka, H. Takeuchi, The knowledge creating company: how Japanese companies create the dynamics of innovation, New York: Oxford University Press, 1995.

[20] S. Paquette, "Customer Knowledge Management". The Encyclopedia of Knowledge Management, D. Schwartz (ed.), Idea Group, 2006. pp. 90-96.

[21] N. Saad, S. Hassan, , L. Shya, "Revisiting the relationship between internal marketing and external marketing: The role of customer orientation". The Journal of Developing Areas, 49(3), 2015. pp. 249262.

[22] M. Schulz, L. A. Jobe, Codification and tacitness as knowledge management strategies: an empirical exploration, The Journal of High Technology Management Research, 12(1), 2001. pp. 139-165.

[23] A. Sergeeva, T. Andreeva, "Knowledge Sharing Research: Bringing Context Back In". Journal Of Management Inquiry. 25(3), 2014. pp. 240-261.

[24] S. Tseng, P. Wu. "The impact of customer knowledge and customer relationship management on service quality". International Journal of Quality and Service Sciences, Vol. 6 Iss: 1, 2014. pp.77 - 96.

[25] UNICEF. Knowledge exchange toolbox. 2015. Retrieved from http://www.unicef.org/knowledge-exchange/ Accessed 21.02.2016.

[26] R. Wayland, P. Cole, Customer connections. Boston, Mass: Harvard Business School Press. 1997.

[27] Young, R. 2010. Knowledge Management Tools and Techniques Manual (1st ed.). Tokyo: APO. Retrieved from http://www.apotokyo.org/00e-books/IS-43_KM-Tools_and_Techniques_2010/IS43 KM-Tools_and_Techniques_2010.p.pdf

[28] M. Zack, Rethinking the knowledge based organization. MIT Sloan Management Review, 44 (4), 2003. pp. 67-71. 